\title{
Synthesis of coloured ceramic pigments by using chromite and manganese ores mixtures
}

\section{(Síntese de pigmentos cerâmicos coloridos usando misturas de cromita e de minérios de manganês)}

\author{
M. H.ALy ${ }^{1}$, I. S. Ismael ${ }^{2}$, F. Bondioli ${ }^{3}$ \\ ${ }^{1}$ Environmental Studies and Research Institute, Minufiya University, Sadat City, Minufiya, Egypt \\ ${ }^{2}$ Geological Department, Faculty of Science Suez, Suez Canal University \\ ${ }^{3}$ Department of Material and Environmental Engineering, University of Modena and Reggio Emilia, 41100 \\ Modena, Italy
}

\begin{abstract}
The aim of this work is not only the synthesis of black ceramic pigment with spinel structure using local and inexpensive minerals (chromite and manganese ores) but also throw some light on the relations between the structure and the colour of obtained pigment. Ultimate utilization spinel solid solution in ceramic materials is mostly due to their structure characteristics, their thermal and chemical stability. In this study colour pigments were ned by calcinations at $1250{ }^{\circ} \mathrm{C}$ starting from a mixture of chromite and manganese oxide. Different compositions were tested containing 30, 40 and $50 \mathrm{wt} \%$ of manganese oxide (low and high content respectively). The phase composition and microstructure characterization of both raw material and obtained pigments were evaluated by X-ray diffraction, X-ray fluorescence, polarizing microscope and scanning electron microscope. Furthermore, the colour measurements of the obtained pigments and tiles were evaluated. Composition of all pigments reveal the spinel structure with $\mathrm{Cr}_{2} \mathrm{FeO}_{4}$; hematite was also recorded in the mixture of low manganese. The degree of lightness is relatively same in the pigments mixtures of both manganese types. However, tiles could be considered lightness compared with its pigments, especially of the high manganese type. The solid state calcinations reactions are indeed able to form intense brown pigments that can be used as a stain for industrial ceramic applications. The production of less expensive black ceramic pigments from low cost and less pure raw materials that can be utilized in Egypt to substitute for the imported pure oxides or salts is proved superior performance for producing painted pigments.
\end{abstract}

Keywords: pigments, chromite, manganese ore, spinel, ceramic industry.

\section{Resumo}

O objetivo deste trabalho é não somente a síntese de pigmento cerâmico negro com estrutura espinélio usando minerais locais e de baixo custo (minérios de cromita e manganês) mas também pesquisar as relações entre a estrutura e a cor dos pigmentos obtidos. $O$ porquê da utilização de soluções sólidas de espinélio em materiais cerâmicos é principalmente devido às características estruturais, estabilidades térmica e química. Neste estudo pigmentos coloridos foram obtidos por calcinação a $1250^{\circ} \mathrm{C}$ partindo-se de mistura de cromita e óxido de manganês. Foram testadas diferentes composições contendo 30, 40 e 50 peso\% de óxido de manganês (alto e baixo teor, respectivamente). A composição de fases e a caracterização microestrutural da matéria-prima e dos pigmentos obtidos foram avaliadas por difração de raios $X$, fluorescência de raios $X$, microscópio óptico com luz polarizada e microscópio eletrônico de varredura. Além disso, foram determinadas as cores dos pigmentos obtidos e dos azulejos. A composição de todos os pigmentos mostra a estrutura espinélio com $\mathrm{Cr}_{2} \mathrm{FeO}_{4}$; hematita foi também detectada na mistura de baixo teor de manganês. $\mathrm{O}$ grau de brilho é relativamente o mesmo em todas as misturas de pigmentos com os dois conteúdos de manganês. Entretanto, os azulejos podem ser considerados brilhantes comparados com seus pigmentos, especialmente o de maior teor de manganês. As reações de calcinação em estado sólido são realmente capazes de formar um pigmento marrom intenso que pode ser usado em aplicações em cerâmica industrial. A produção de pigmentos cerâmicos negros a partir de matéria-prima de menor custo e menor teor de pureza, que podem ser utilizadas no Egito para substituir os óxidos e sais puros, mostrou desempenho melhor para a produção de pigmentos pintados. Palavras-chave: pigmentos, cromita, minério de manganês, espinélio, indústria cerâmica.

\section{INTRODUCTION}

The term pigments is applied to black, white or colored organic or inorganic powders that are insoluble in the substrate in which they are incorporated and are not chemically and physically altered by it [1]. Pigments used in the production of traditional colored glazed and unglazed tile must show thermal and chemical stability at high temperatures (1200$1250{ }^{\circ} \mathrm{C}$ ). The first step, in pigment production, is the selection of raw materials which are mostly metallic oxides 
or salts of the desired metals with industrial chemical purity.

The most important brown and black pigments used in ceramic coatings are the iron chromite spinels generally synthesized from mixture of iron oxide $\left(\mathrm{Fe}_{2} \mathrm{O}_{3}\right)$ and chromium oxide $\left(\mathrm{Cr}_{2} \mathrm{O}_{3}\right)$ by calcinations above $1000{ }^{\circ} \mathrm{C}[2$, 3]. Some of the black spinel pigments contain also other elements such as cobalt, manganese, nickel or copper. The cobalt free iron-chromium pigments have been the focus of renewed interest in recent years because of the increase in the price of cobalt-bearing black pigments and its pollution problems [4]. It was suggested that preparation of $(\mathrm{Fe}, \mathrm{Cr})_{2} \mathrm{O}_{3}$ solid solution as black pigments [4].

They used both mechanical mixing of oxides and coprecipitation of hydroxides to prepare a homogeneous mixed that were successively calcined to obtain the black pigments. This pigments appeared to be composed of a solid solution of $(\mathrm{Cr}, \mathrm{Fe})_{2} \mathrm{O}_{3}$ type, with prevalence of $\mathrm{Cr}_{1.3} \mathrm{Fe}_{0.7} \mathrm{O}_{3}$. The synthesis of an iron-chromium ceramic pigments by using limonite and chromite mixtures was investigated [5]. They mentioned that the chromite and limonite mixtures can be used as raw materials to obtain colors from dark brown to light brown depending on the calcinations temperature and chromite or limonite content.

Between the brown and black pigments are also manganese - chromite spinels that are prepared by calcinations of manganese oxide $(\mathrm{MnO})$ and chromium oxide $\left(\mathrm{Cr}_{2} \mathrm{O}_{3}\right)$ above $1000{ }^{\circ} \mathrm{C}$. This study is concerned with the evaluation of Egyptian manganese and chromite ores for the production of black ceramic pigments in order to substitute the imported pure oxides or salts. Pigments are an important part of the ceramic industries and most of these pigments are produced from expensive pure oxides and salts. Ceramic companies in Egypt are importing the pigment raw materials and the preparation of low cost even if less pure raw materials could be very interesting to produce commercial colors.

Chromite $\left(\mathrm{FeO} \mathrm{Cr}_{2} \mathrm{O}_{3}\right)$ is an important mineral used in refractories and as a colouring agent in enamel [6-8]. Chromite is characterized by high thermal and chemical stability compared with other minerals oxides, and can be used as inexpensive natural raw material to produce pigments. It is also reported that chromite addition to commercial black pigments reduced the cost of colouring glaze [9]. However, when raw chromite is used as colouring agent in glaze, brown spots may be produced and colour changes from yellow to brown depending on glaze composition.

Manganese oxides ore $(\mathrm{MnO})$ can widely be found in the earth crust; $\mathrm{MnO}$ is a strategic oxide that has several industrial applications such as in steel production, carbonzinc batteries production, fertilizers, as well as colorants for bricks, dyes and medicines [10]. The mineral commonly founded is pyrolusite that is sometimes added to red earths to create darker red, violet or black colors in pottery clays or glazes.

The aim of this work is not only the synthesis of black ceramic pigment with spinel structure using local and inexpensive minerals (chromite and manganese ores) but also throw some light on the relations between the structure and the colour of obtained pigment.

\section{Sampling localities}

Two manganese ore samples (high and low manganese content) were selected from Um Bogma area, situated in west central Sinai, $20 \mathrm{~km}$ east of the Gulf of Suez and 30 km south east of Abu Zenima (Fig. 1). Manganese deposits of Um Bogma form lenses in dolomitic and sandy beds at the based of Carboniferous sequence. The ore lenses are 1 to $200 \mathrm{~m}$ in diameter and up to $6 \mathrm{~m}$ thick $[11,12]$. Chromite sample is selected from Abu Dahr area at about $3 \mathrm{~km}$ southeast of Bir Bitan (Fig. 1). Chromite occurs mainly as lenticular bodies of variable dimensions generally less than $10 \mathrm{~m}$, commonly hosted by serpentinites [13].

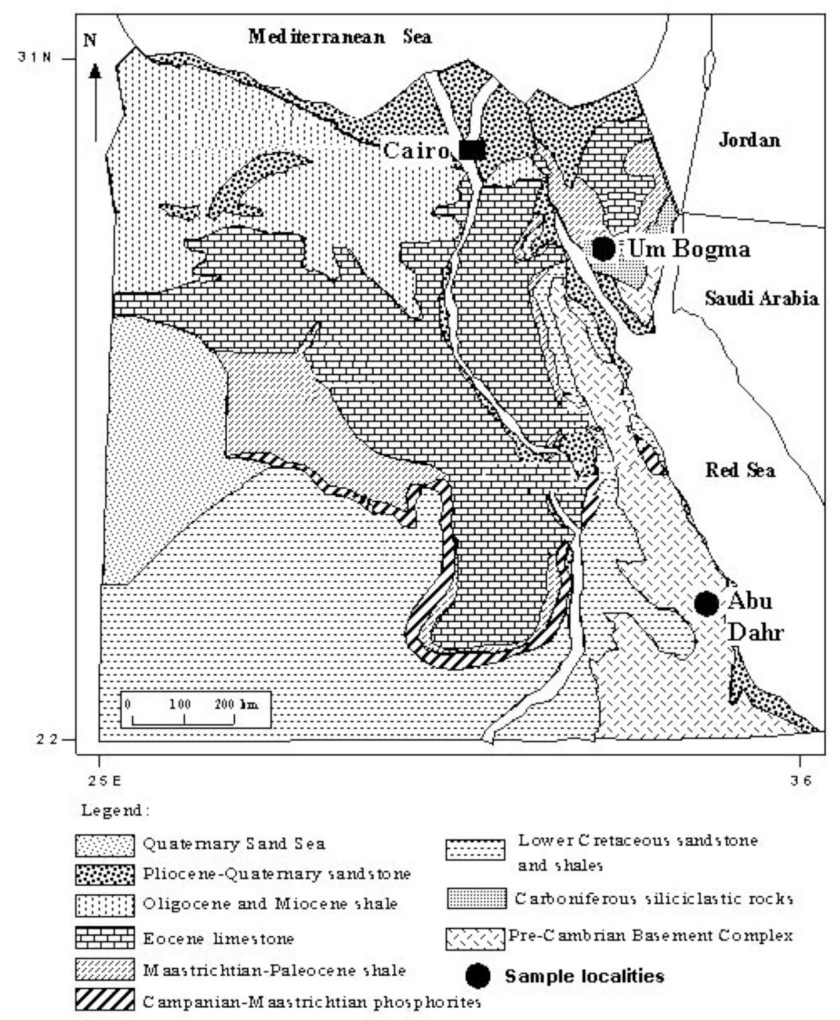

Figure 1: Geological location map of the studied samples. [Figura 1: Mapa da localização geológica das amostras.]

\section{EXPERIMENTAL PROCEDURE}

Chromite and manganese oxide mixtures containing 30, 40 and $50 \mathrm{wt} . \%$ of manganese oxide (low and high content respectively) were prepared. The mixtures were wet milled for three hrs in a ball mill and then dried. Each mixture was calcined for three hrs at $1250{ }^{\circ} \mathrm{C}$. The calcined product was wet grounded for $1 \mathrm{~h}$ in a ball mill, washed, filtered and then dried.

After drying, the powders were tested as pigments for ceramic body coloring. A ceramic body, having a typical 
composition for gres porcellanato was used for pigment application. The pigments, added to the composition at $3 \mathrm{wt} . \%$, were dry mixed for $30 \mathrm{~min}$. The mixtures were pressed at $400 \mathrm{~kg} / \mathrm{m}^{2}$ and then fired at $1250{ }^{\circ} \mathrm{C}$ for $40 \mathrm{~min}$ following an industrial cycle.

The chemical composition of raw materials were determined using Philips PW1410 X-ray fluorescence (XRF) at $50 \mathrm{kV}$ and $40 \mathrm{~mA}$. The mineralogical composition of raw materials and the crystalline phases obtained after calcinations were determined using Philips PW 1710 X-ray diffractometer (XRD), using $\mathrm{Cu}$ radiation $\left(\mathrm{K}_{\alpha}=1.5418 \AA\right.$ ) at $40 \mathrm{kV}$ and $20 \mathrm{~mA}$ and $\mathrm{Ni}$ filter, with a scanning speed of two theta degree per minute. Colour measurements were performed using a colorimeter (Minolta CR 300) based on the CIE (Commission Internationale del'Eclarirage) system and the results were expressed as Hunter $L^{*} a^{*} b^{*}$ values. The colour measurements were carried out on pigments and colored tiles. Petrography of the natural raw materials were studied using Zeiss polarizing microscope, while grain and aggregate size of the obtained pigments were identified by SEM analysis using a Philips XL 30.

\section{RESULTS AND DISCUSSION}

The chemical composition of natural chromite, low and high manganese ores are listed in Table I.

Table I - Chemical composition of natural raw materials used.

[Tabela I - Composição química das matérias primas.]

\begin{tabular}{cccc}
\hline $\begin{array}{c}\text { Element } \\
\text { oxides }\end{array}$ & $\begin{array}{c}\text { Chromite } \\
\text { wt \% }\end{array}$ & $\begin{array}{c}\text { Low } \\
\text { manganese } \\
\text { wt \% }\end{array}$ & $\begin{array}{c}\text { High } \\
\text { manganese } \\
\text { wt \% }\end{array}$ \\
\hline $\mathrm{SiO}_{2}$ & 3.10 & 3.60 & 2.50 \\
$\mathrm{Fe}_{2} \mathrm{O}_{3}$ & 23.50 & 71.42 & 13.41 \\
$\mathrm{Al}_{2} \mathrm{O}_{3}$ & 17.42 & 0.61 & 0.92 \\
$\mathrm{Cr}_{2} \mathrm{O}_{3}$ & 62.34 & 0.52 & 0.51 \\
$\mathrm{MnO}$ & 0.33 & 19.93 & 78.83 \\
$\mathrm{MgO}$ & 9.26 & 0.30 & 1.25 \\
$\mathrm{CaO}$ & 0.17 & 2.59 & 0.86 \\
\hline
\end{tabular}

Table I clearly shows that the chromite sample has $\mathrm{Cr}_{2} \mathrm{O}_{3}$ content of about $62.34 \%$ and $\mathrm{Fe}_{2} \mathrm{O}_{3}$ content of about $23.50 \%$. On the other hand, high manganese ore sample has $\mathrm{MnO}$ content of about $78.83 \%$ and $\mathrm{Fe}_{2} \mathrm{O}_{3}$ content of about $13.41 \%$, while in the low manganese ore sample the ratio between these two oxides is almost reversed (MnO 20wt.\%; $\left.\mathrm{Fe}_{2} \mathrm{O}_{3} 71.5 \mathrm{wt} . \%\right)$. $\mathrm{SiO}_{2}$ is relatively the same in all samples, while chromite demonstrated enriched in $\mathrm{Al}_{2} \mathrm{O}_{3}$ compared with manganese ores.

The X-ray diffraction patterns of nature raw materials are show in Fig. 2. From this figure it clear to note that, chromite ore is mainly contain chromite and small amount of antigorite and trace amount of chlorite, while low manganese

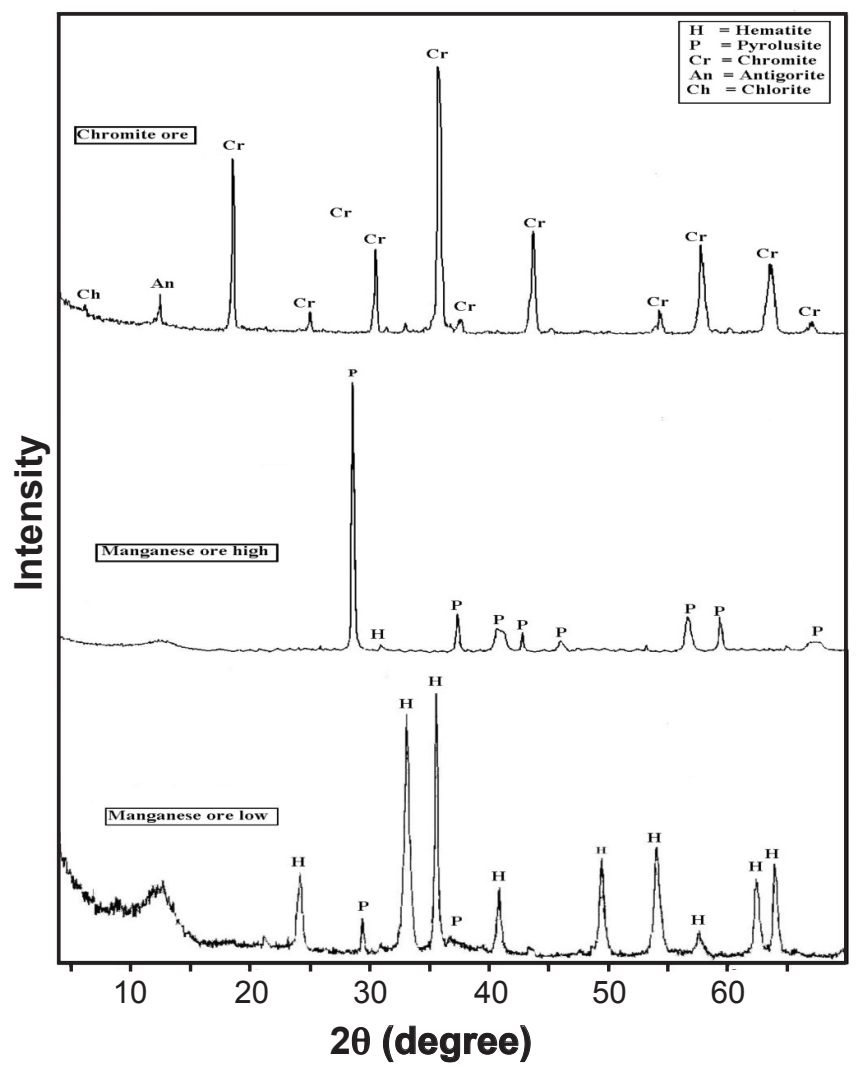

Figure 2: X-ray diffraction patterns of raw materials.

[Figura 2: Difratogramas de raios $X$ das matérias primas.]

ore is mainly composed of hematite with small amount of pyrolusite. On the contrary, high manganese ore is mainly composed of pyrolusite and small amount of hematite.

Reflected-light microscopy investigation shows that chromite is the main mineral in the chromite ore with grayish and low reflectivity grains, usually cracked and filled with serpentinites (Figs. 3a and 3b). Manganese ore shows, in good agreement with XRD results, that pyrolusite is the main Mn-oxides mineral present. Hematite is common within Mn-oxide grains, particularly at the contact of cracked planes (Fig. 3c). Pyrolusite, alternative with hematite and goethite, forming zones, in some case hematite and goethite are filled voids between pyrolusite crystals (Fig. 3d).

Absence of manganese phases lines from X-ray diffraction patterns, may be reveals presence manganese as amorphous phase.

The X-ray patterns of obtained pigments are reported in (Fig. 4). The figure shows that at $1250{ }^{\circ} \mathrm{C}$, the spinel structure " $\mathrm{Cr}_{2} \mathrm{FeO}_{4}$ " is formed independently from the starting raw materials even if hematite is also recorded in the mixture obtained starting from low manganese ore. Absence of manganese phases lines from X-ray diffraction patterns, may be reveals presence manganese as amorphous phase.

SEM analysis of pigments shows that they are mainly composed of a spherical or subspherical grains, its size ranges from 75-100 $\mu \mathrm{m}$, the individual grain shows a concentrically band structure, these bands are alternative with each other (Figs. 5a and 5b). 

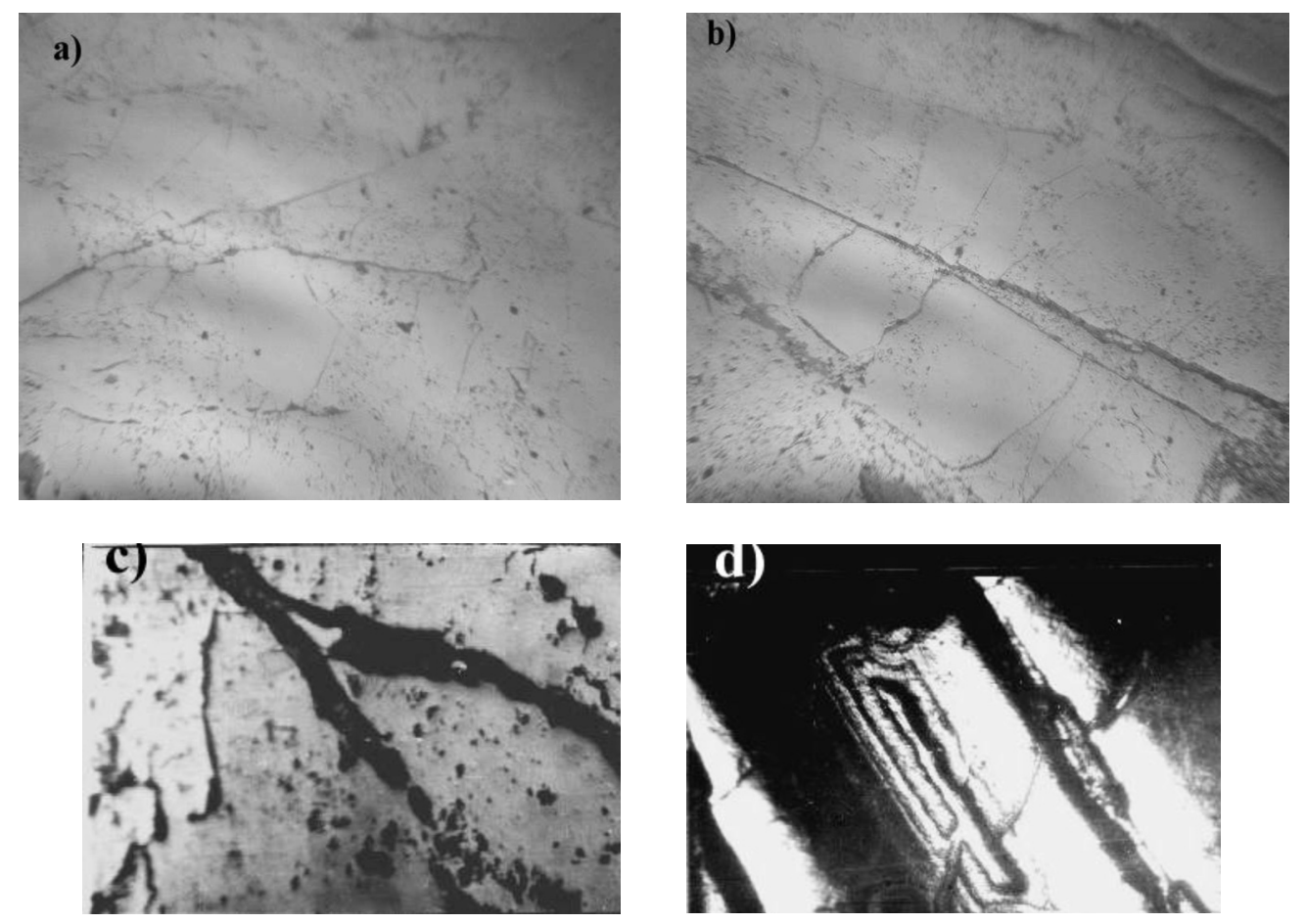

Figure 3: Photomicrographs (a and b) of chromite grains show cracked grayish chromite grains. Photomicrographs (c and d) of manganese ore, where hematite in contact cracked or forming zones (Reflected light $\mathrm{x}=200$ ).

[Figura 3: Fotomicrografias (a e b) dos grãos de cromita mostrando grãos de cromita cinza. Fotomicrografias (c e d) de minério de manganês, onde hematita em contato quebraram ou formaram zonas (luz refletida $x=200$ ).]



Figure 4: X- ray diffraction patterns of calcined mixture materials. [Figura 4: Difratogramas de raios $X$ dos materiais misturados calcinados.]
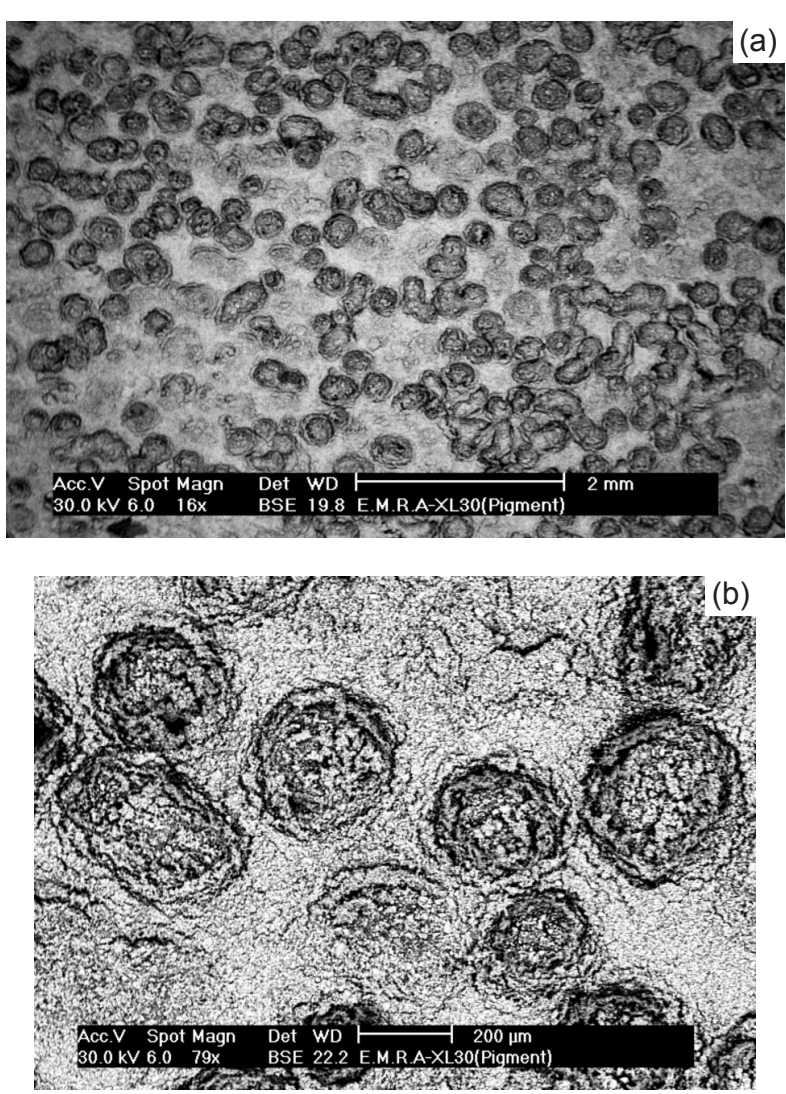

Figure 5: SEM images (a and b) of pigments.

[Figura 5: Imagens de microscopia eletrônica de varredura (a e b) dos pigmentos.] 


\section{Colour measurements}

The measured values (Fig. 6) indicate that the degree of lightness of pigments, in relation to the scale that extends from white $\left(\mathrm{L}^{*}=100\right)$ to black $\left(\mathrm{L}^{*}=0\right)$, is not influenced by the change of manganese content using low or high type. However L* values change considerably in tiles increasing the manganese content. In particular tiles are generally

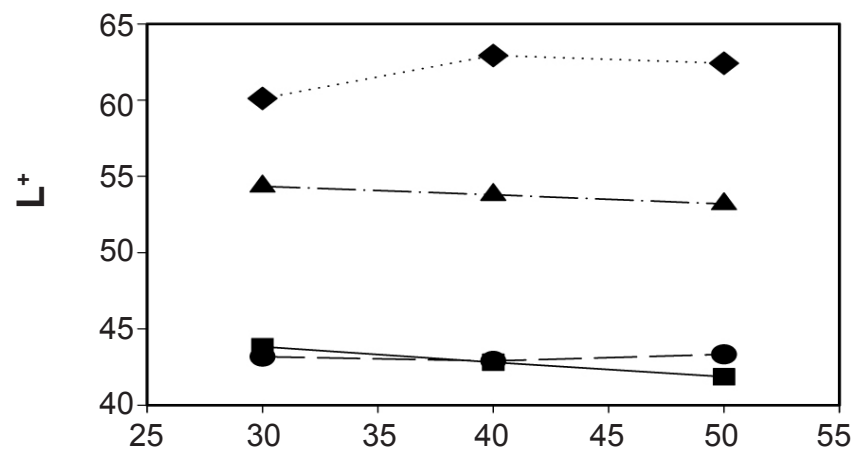

Chromite - manganese mixtures percentage
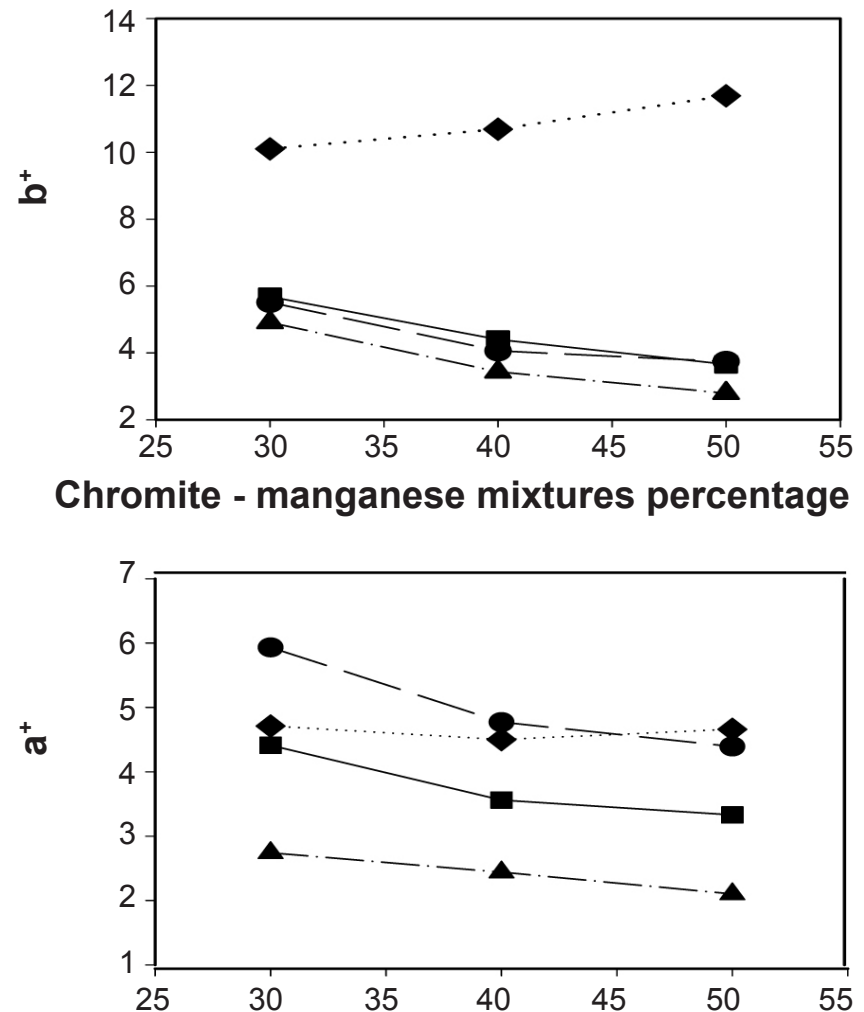

Chromite - manganese mixtures percentage

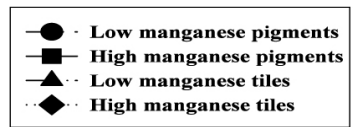

Figure 6: The relationship between $L^{*} a^{*} b^{*}$ values and chromite manganese mixture percentage (pigments and tiles).

[Figura 6: Relação entre valores de $L^{*} a^{*} b^{*}$ e a porcentagem da mistura cromita manganês (pigmentos e azulejos).] lightness compared with pigments, especially those with high manganese type.

Hunter $b^{*}$ values, in relation to the scale extending from blue $\left(-b^{*}\right)$ to yellow $\left(+b^{*}\right)$, are also not influenced by the manganese ore used. Finally the $a^{*}$ values in relation to the scale extending from green $\left(-\mathrm{a}^{*}\right)$ to red $\left(+\mathrm{a}^{*}\right)$, increase with increasing low manganese ore in pigments due to the higher content of red free hematite.

\section{CONCLUSION}

Local Egyptian chromite and manganese ores can be used as inexpensive raw materials to obtained colours pigments. Two manganese ore samples (high and low manganese content) were selected from Um Bogma area, situated in west central Sinai, and the other chromite sample is selected from Abu Dahr area. The colour pigments were prepared by the calcinations of chromite and manganese oxide mixtures containing 30,40 and $50 \mathrm{wt} \%$ of manganese oxide (low and high content respectively) were prepared. In particular the mixtures during that calcination at $1250{ }^{\circ} \mathrm{C}$ form a spinel structure of $\mathrm{Cr}_{2} \mathrm{FeO}_{4}$ type independently on the composition and mineral used. The colours of pigment range from dark black to light grey depending on chromite or manganese content. Pigments structure has a spherical or subspherical grains, with grain size ranging from 75 to $100 \mu \mathrm{m}$.

\section{REFERENCES}

[1] P. A. Lewis, Pigment Handbook, Vol. I - Properties and Economics, $2^{\text {nd }}$ Ed., John Wiley \& Sons, New York, USA (1988) $945 \mathrm{pp}$.

[2] A. Escardino, S. Mestre, A. Barba, V. Beltran, A. Blasco, Synthesis Mechanism of an Iron-Chromium Ceramic Pigment , J. Am. Ceram. Soc. 83, 1 (2000) 29-32.

[3] A. Escardino, S. Mestre, A. Barba, V. Beltran, A. Blasco, Kinetic Study of Black $\mathrm{Fe}_{2} \mathrm{O}_{3}-\mathrm{Cr}_{2} \mathrm{O}_{3}$ Pigment Synthesis: I, Influence of Synthesis Time and Temperature, J. Am. Ceram. Soc. 86, 6 (2003) 945-950.

[4] T. Manfredini, F. Bondioli, M. Romagnoli, Preparation of $(\mathrm{Fe}, \mathrm{Cr})_{2} \mathrm{O}_{3}$ solid solution as black pigment, Int. Ceram. J. (2000).

[5] E. Ozel, I. Kucuk, S. Turan, Synthesis of an IronChromium ceramic pigment by using Limonite and Chromite mixtures, Eng. Mater. 206-213 (2002) 187-1830.

[6] S. H. Murdock, R. A. Eppler, Zinc Iron Chromite Pigments, J. Am. Ceram. Soc. 71, 4 (1988) C212-214.

[7] R. I. Lazau, C. Pacurariu, D. Becherescu, R. Ianos, Ceramic pigments with chromium content from leather wastes, J. Eur. Ceram. Soc. 27, 2 (2007) 1899-1903.

[8] E. Ozel, G. Unluturk, S. Turan, Production of brown pigments for porcelain insulator applications, J. Eur. Ceram. Soc. 26, 4 (2006) 735-740.

[9] E. Ozel, S. Turan, Production and characterisation of ironchromium pigments and their interactions with transparent glazes, J. Eur. Ceram. Soc. 23, 12 (2003) 2097-2104.

[10] R. N. Sahoo, R. K. Srinivasa, Sulphating-roasting of 
low-grade manganese ore: optimization by factorial design, Int. J. Miner. Process. 25, 1-2 (1989) 147-152

[11] A. M. Morsy, H. A. Hussein, A. M. El Fiky, Sedimentology of the Paleozoic in East Central Sinai. Proc. $3^{\text {rd }}$ Conf. Geol., Ismailia (1992) 113-126.

[12] G. S. Roufaiel, N. N. Yanni, K. M. Amer, Contribution to the study of manganese-iron deposits at Um Bogma area, Sinai. M.E.R. Ain Shams Univ., Earth Sci. 1 (1987) 98-107. [13] L. S. Ismael, Mineralogy and petrology of some chromite ores in the Eastern Desert, Egypt, B.Sc. Thesis, Faculty of Science, Ain Shams Univ., Cairo (1990) 84pp.

(Rec. 15/05/2009, Ac. 01/03/2010) 